\title{
Interleaved quadratic boost converter integrated with Dickson voltage multiplier with energy storage for high power photo voltaic applications
}

\author{
D. Amudhavalli ${ }^{1}$, Nalin Kant Mohanty ${ }^{2}$, Ashwin Kumar Sahoo ${ }^{3}$ \\ ${ }^{1,2}$ Department of Electrical and Electronics Engineering, Sri Venkateswara College of Engineering, Tamil Nadu, India \\ ${ }^{3}$ Department of Electrical and Electronics Engineering, C. V. Raman Global University, Bhubaneswar, Odisha, India
}

\begin{tabular}{l} 
Article Info \\
\hline Article history: \\
Received Jan 6, 2021 \\
Revised Apr 3, 2021 \\
Accepted Apr 15, 2021 \\
\hline
\end{tabular}

Keywords:

Interleaved converters

Photovoltaic

Quadratic boost converter

Voltage multiplier cell

\begin{abstract}
In this paper interleaved quadratic boost converter with Dickson voltage multiplier is proposed. Photovoltaic system is connected to high power load through the proposed converter. Structure of this high gain interleaved converter comprised of two stages: interleaved quadratic boost converter stage and Dickson voltage multiplier stage. Interleaved quadratic boost converter is a parallel combination of two quadratic boost converter. The interleaving increases frequency of converter that could be filtered using small capacitors, making input current smoother than the current of conventional quadratic boost converter. Thus, interleaved circuit minimizes current ripple present in input current, cascading of voltage multiplier cell increases the gain voltage ratio of converter making it suitable for high power, high voltage gain photo voltaic applications. Stress voltage of the switches and reverse recovery problems gets reduced, thereby reducing EMI problems. $300 \mathrm{~W}$ prototype capable of increasing $24 \mathrm{~V}$ input voltage to $400 \mathrm{~V}$ output voltage is designed and results tested using MATLAB/Simulink software. Hardware prototype is also implemented to verify simulation results. Also, application of this converter in integrated energy storage is demonstrated.
\end{abstract}

This is an open access article under the CC BY-SA license.

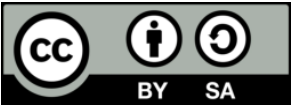

\section{Corresponding Author:}

D. Amudhavalli

Departement of Electrical and Electronics Engineering

Sri Venkateswara College of Engineering

Sriperumbudur, Tamil Nadu, India

Email: amudhavalli@svce.ac.in

\section{INTRODUCTION}

Demand for electricity is consistently increasing throughout the globe year by year [1], [2]. The choice for supplying electricity produced from fossil fuel would not be a good option, because of their adverse effects like, continuous change in climatic conditions as a threat created by increasing emission of greenhouse gasses, by burning of fossil fuels [3]. Hence the entire world is turning towards generation of electricity using RES like wind, fuels cell and photovoltaic. Among them photovoltaic power is analyzed as promising electrical power generation systems, as sunshine required to generate electricity is available throughout the year and also it is available globally.

Recently Nano-grid concepts are introduced to utilize photovoltaic power and supplement the existing main grid efficiently, especially at remote rural areas [4], [5]. They are becoming a solution for providing electricity because of their advantages like (i) easy construction of renewable energy systems, (ii) ability to operate in both grid-connected and standalone mode and (iii) providing excess power generated either to grid 
or battery swapping stations [6]. In this model generally motor loads are supplied by using inverter and the DC loads like DC fan, DC lights and electric vehicles are supplied directly from solar panel. Photovoltaic power available at low voltage levels has to be increased in level to satisfy the load voltages, especially when supplying 230V AC, where DC power has to be converted to AC by the inclusion of inverter [7], DC power available in photovoltaic panel has to be increased from $24 \mathrm{~V}$ to $400 \mathrm{~V}$, for this DC converter plays a vital role. Challenging task is that the design should involve converters with large stepping up ratio and more efficiency. Boost converter used conventionally produces higher voltages only at higher duty ratios, leading to increased losses and decreased efficiency; moreover, it also leads to reverse recovery losses and requires use of large inductors to maintain continuous conduction stage leading to the accommodation of bulky magnetics. Hence two boost converters were connected in series, named cascaded converters, to obtain higher voltages at low duty ratios. This model involves provision of gate pulse to two separate switches; increasing complexity of the system operation especially when converter is operated in closed loop. To overcome this disadvantage single switch cascaded converters were introduced and were named Quadratic boost converter that is capable of increasing the input voltage to larger value [8], [9].

Many converters were designed to obtain high voltage gain by incorporating switched inductors or transformers [10], [11]. These topologies increase voltage gain by increasing turns ratio of the converter, but this leads to issues like, voltage spikes across switching devices urging to inclusion of Active clamping circuits [12]. It also reduces power density of converter and increases weight. Since the technological improvements made in semiconductor materials are faster than improvements made in magnetic materials, any suggestion to increase the power density of the converter by increasing its switching frequency increases losses occurring in magnetic materials, introducing them as severe culprits. A step-up DC-DC converter composed of resonant voltage doubler and active clamp circuit is proposed [13]. The active clamp circuit reduces the voltage stress of the switch to a maximum of input voltage and resonant voltage doubler aids to zero current switching turn-off of diodes reducing losses occurring due to reverse recovery of diode.

With switched capacitor (SC), the voltage gain is increased by charging in parallel and discharging in series [14]-[16]. Generalized fundamental limit theory in SC sets voltage gain ratio for k-flying capacitors in SCs were given [17]. This limit was acceptable for positive voltage-gain ratio, it was also discussed for negative voltage-gain ratio and multiple input and multiple output system. Efficiency of capacitor charging/discharging RC circuit was discussed [18], complete evaluation of overall efficiency was made and design rules were suggested for developing high efficiency SC. But as the voltage gain is increased, the numbers of SCs were increased making the converter complex and also flowing of high charging current through the switch is considered to be a drawback that increases conduction loss.

Two-stage converter consisting of interleaved boost converter with bifold Dickson Voltage multiplier for interfacing renewable energy sources to high voltage applications. It offers high voltage gain with low voltage stress on switches and passive components. Inductor currents are said to be equal regardless of number of VMCs. This equal sharing of current reduces conduction losses in active switches, improving overall efficiency, as the conduction power is a quadratic function [19]. Interleaved converter that is capable of drawing power from either a single source or two independent sources. Further voltage multiplier uses low voltage rating capacitors that leads to size reduction [20]. Very high voltage gains interleaved converter that uses two coupled inductors and voltage multiplier cell. This converter also holds all advantages of interleaved boost converter with voltage multiplier cell. Further reverse recovery problem is mitigated and the leakage energy is recycled and also implementing low voltage rated MOSFETs with a small ON-resistance, conduction losses is reduced, improving efficiency of converter [21], [22]. Three winding coupled inductors, voltage multiplier cell and a clamp circuit is proposed. Step-up voltage gain is increased owing to voltagestack and voltage lift techniques using voltage multiplier cells. Leakage inductor energy is recycled by the clamp circuit to avoid the voltage surge on power switch. Moreover, this converter also holds the advantages of interleaved converters [23], [24].

Due to the advantages of interleaved converters and voltage multiplier cells a high voltage gain converter is proposed in this paper. High voltage gain is obtained by connecting Dickson Voltage Multiplier in series with interleaved quadratic boost converter. Proposed converter comprises of two stages: first stage is interleaved boost stage and second is the voltage multiplier stage. Interleaving shares input current equally in parallel connected converters, reducing input ripple occurring in source, making converter input current magnitude more suitable for maximum power point algorithms [25]-[28] and second stage increases overall voltage gain of converter [29]-[31]. Hence the converter includes the advantages of both interleaving and Voltage Multiplier Cell. The paper is organized in the following way. Section 2 elaborates modes of operation and steady state equations of converter. Section 3 displays the simulation results; Section 4 describes hardware results and Section 5 concludes the paper suggesting an application of the proposed converter. 


\section{OPERATION OF CIRCUIT}

Interleaved quadratic boost converter with Dickson Voltage multiplier cell is shown in Figure 1(a). The converter proposed consists of two capacitors and inductors, with four diodes and nVMC cells. Single VMC cell consist of two diode and two capacitors.

To simplify the operation principle and steady state analysis, only two VMC are considered. Rearranged circuit is shown in Figure 1 (b). Switching pattern for the converter proposed is shown in Figure 1 (c). Gate driving is given. Mode 1 shown in Figure 2 (a), switch $S_{1}$ and $S_{2}$ are ON, hence diode $D_{1}$ and $D_{3}$ becomes $\mathrm{ON}$ and diodes $\mathrm{D}_{2}$ and $\mathrm{D}_{4}$ becomes OFF. Inductors $\mathrm{L}_{1}$ and $\mathrm{L}_{3}$ are charged by source voltage and inductors $\mathrm{L}_{2}$ and $\mathrm{L}_{4}$ are charged by charge stored in capacitor $\mathrm{C}_{1}$ and $\mathrm{C}_{2}$. Since the two quadratic converters are shorted by switches $S_{1}, S_{2}$ no current is passed from source to load. Current in load is supplied by charge stored in capacitor $\mathrm{V}_{\mathrm{C} 2 \mathrm{~A}}$ and $\mathrm{V}_{\mathrm{C} 2 \mathrm{~B}}$.

$$
\begin{aligned}
& V_{L 1}=V_{d c} \\
& V_{L 2}=V_{C 1} \\
& V_{L 3}=V_{d c} \\
& V_{L 4}=V_{C 2}
\end{aligned}
$$

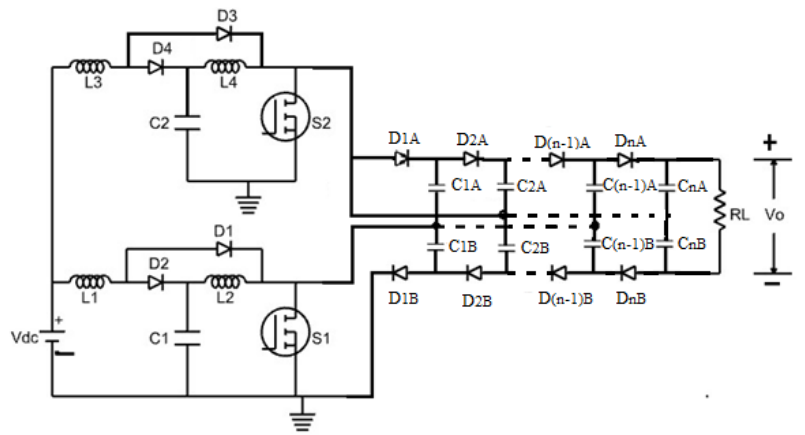

(a)

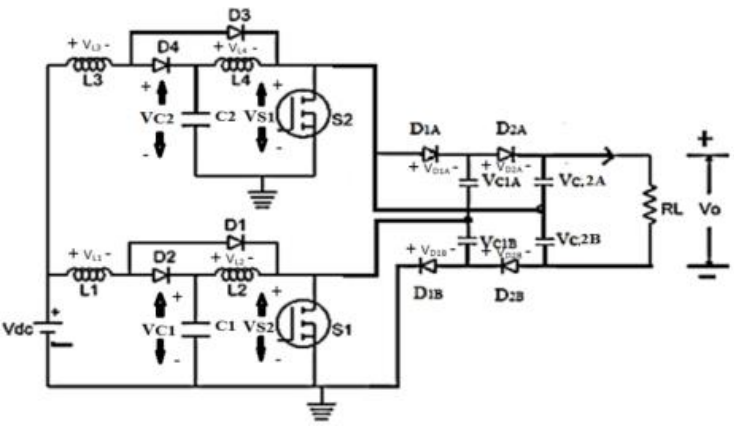

(b)

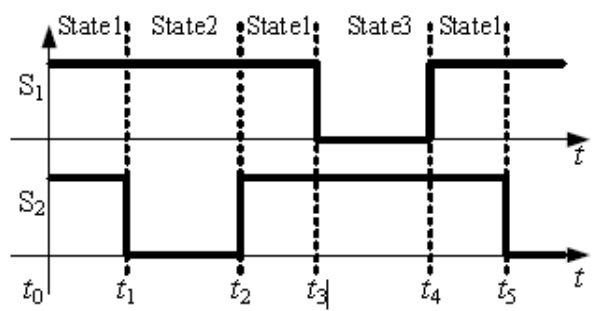

(c)

Figure 1. (a) interleaved quadratic boost converter with Dickson voltage multiplier cell, (b) with two Dickson voltage multiplier cell, and (c) Switching pulse for the interleaved quadratic boost converter with VMC

Mode 2 shown in Figure 2 (b), among the two switches, $S_{2}$ is made $\mathrm{ON}$ and $\mathrm{S}_{1}$ is made OFF, hence diode $\mathrm{D}_{3}$ becomes $\mathrm{ON}$ and $\mathrm{D}_{4}$ becomes $\mathrm{OFF}$ by capacitor voltage $\mathrm{V}_{\mathrm{C} 2}$, by this inductor $\mathrm{L}_{3}$ gets charged with input voltage $\mathrm{V}_{\mathrm{dc}}$, $\mathrm{L}_{4}$ comes in parallel with capacitor $\mathrm{C}_{2}$ and it gets charged by energy present in $\mathrm{C}_{2}$. However, switch $S_{1}$ is made OFF, $D_{1}$ gets reverse biased making $D_{2}$ is forward biased, now current from source flows through $\mathrm{L}_{1}, \mathrm{D}_{2}, \mathrm{~L}_{2}$ through VMC and one portion through $\mathrm{S}_{2}$.

$$
\begin{aligned}
& V_{L 1}=V_{d c}-V_{C 1} \\
& V_{L 2}=V_{C 1}-\left(V_{C 2 A}-V_{C 1 A}\right) \\
& V_{L 3}=V_{d c}
\end{aligned}
$$




$$
V_{L 4}=V_{C 2}
$$

Mode 3 shown in Figure 2(c), among the two switches $S_{1}$ is made $O N$ and $S_{2}$ is made OFF, hence $D_{1}$ becomes $O N$ and $D_{2}$ becomes OFF by capacitor voltage $V_{C 1}$, by this inductor $L_{1}$ gets charged by input voltage $V_{d c}, L_{2}$ comes in parallel with capacitor $C_{1}$ gets charged by energy present in capacitor $C_{1}$. However, switch $S_{2}$ is made OFF, $D_{3}$ is reversed biased and $D_{4}$ is forward biased; now current from source flow in inductor $\mathrm{L}_{3}$, diode $\mathrm{D}_{4}$, inductor $\mathrm{L}_{4}$ through $\mathrm{VMC}$ completes its path through switch $\mathrm{S}_{1}$. Voltage equations of inductors $\mathrm{L}_{1}, \mathrm{~L}_{2}, \mathrm{~L}_{3}$ and $\mathrm{L}_{4}$ are

$$
\begin{aligned}
& V_{L 1}=V_{d c} \\
& V_{L 2}=V_{C 1} \\
& V_{L 3}=V_{d c}-V_{C 2} \\
& V_{L 4}=V_{C 2}-V_{C 1 A}
\end{aligned}
$$

Applying Volt-balance equation to the inductance

$$
\begin{aligned}
& \int_{t_{0}}^{t_{1}} V_{d c} d t+\int_{t_{1}}^{t_{2}}\left(V_{d c}-V_{C 1}\right) d t+\int_{t_{2}}^{t_{3}} V_{d c} d t+\int_{t_{3}}^{t_{4}} V_{d c} d t=0 \\
& \int_{t_{0}}^{t_{1}} V_{d c} d t+\int_{t_{1}}^{t_{2}} V_{d c} d t+\int_{t_{2}}^{t_{3}} V_{d c} d t+\int_{t_{3}}^{t_{4}}\left(V_{d c}-V_{C 2}\right) d t=0 \\
& \int_{t_{0}}^{t_{1}} V_{C 1} d t+\int_{t_{1}}^{t_{2}}\left(V_{C 1}-\left(V_{C 2 A}-V_{C 1 A}\right)\right) d t+\int_{t_{2}}^{t_{3}} V_{C 1} d t+\int_{t_{3}}^{t_{4}} V_{C 1} d t=0 \\
& \int_{t_{0}}^{t_{1}} V_{C 2} d t+\int_{t_{1}}^{t_{2}} V_{C 2} d t+\int_{t_{2}}^{t_{3}} V_{C 2} d t+\int_{t_{3}}^{t_{4}}\left(V_{C 2}-V_{C 1 A}\right) d t=0
\end{aligned}
$$

By solving above equation voltage across capacitor is

$$
V_{C 1 A}=V_{C 1 B}=\frac{V_{d c}}{(1-D)^{2}} ; V_{C 2 A}=V_{C 2 B}=\frac{2 V_{d c}}{(1-D)^{2}}
$$

Hence

$$
V_{0}=\frac{4 V_{d c}}{(1-D)^{2}}
$$

Now, voltage gain ratio for inclusion of two VMCs is calculated from (19) and is given below

$\frac{V_{0}}{V_{d c}}=\frac{4}{(1-D)^{2}}$

Voltage gain of nVMCs is given by

$$
V_{0}=\frac{4 n V_{d c}}{(1-D)^{2}}
$$

and the capacitor voltages are

$$
V_{C 1 A}=V_{C 1 B}=\frac{n V_{d c}}{(1-D)^{2}} ; V_{C 2 A}=V_{C 2 B}=\frac{2 V_{d c}}{(1-D)^{2}}
$$




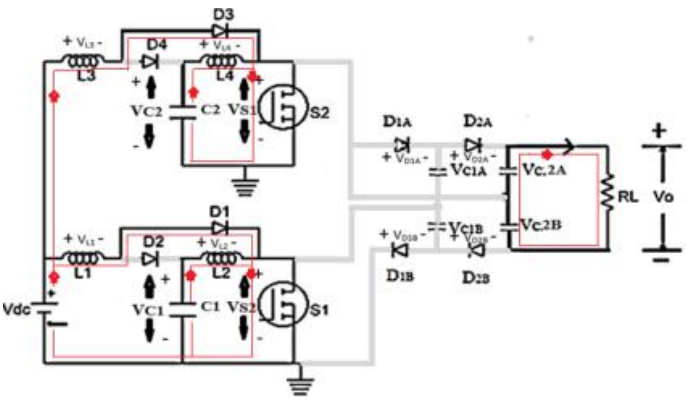

(a)

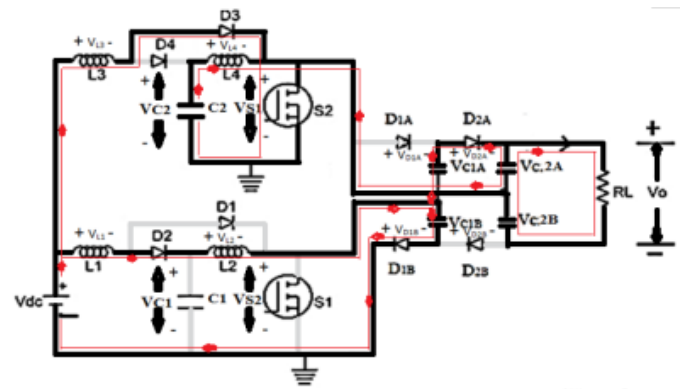

(b)

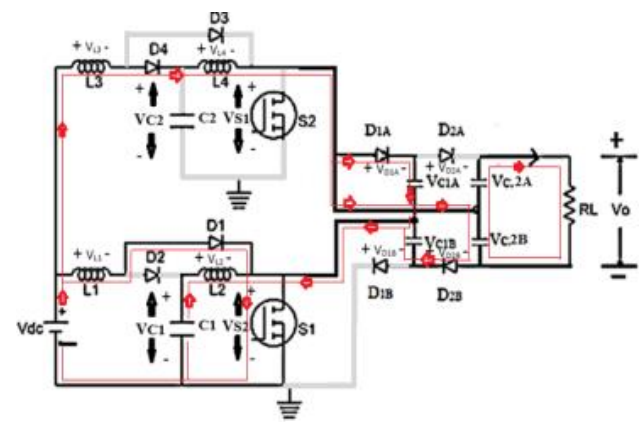

(c)

Figure 2. (a) mode 1 operation, (b) mode 2 operation, and (c) mode 3 operation of the circuit

\subsection{Selection of inductor}

Average value of inductor current depends upon the load current and number of VMCs. Equation for average current is given by

$$
I_{\text {in }}=\frac{2 n I_{O}}{(1-D)^{2}}
$$

Input current is shared with inductors of two interleaved QBC is calculated as

$$
I_{L 1 \text { avg }}=I_{L 2 \text { avg }}=\frac{I_{\text {in }}}{2}=\frac{n I_{O}}{1-D}
$$

As inductor current ripple decides the value of inductor. Equations of $\mathrm{L}_{1}$ and $\mathrm{L}_{2}$ are

$$
L_{1}=\frac{V_{\text {in }}}{\Delta i_{L 1} f_{S}} ; L_{3}=\frac{V_{\text {in }}}{\Delta i_{L 3} f_{S}} ; L_{2}=\frac{V_{c 1} D}{\Delta i_{L 2} f_{S}} ; L_{4}=\frac{V_{c 2} D}{\Delta i_{L 4} f_{S}}
$$

\subsection{Efficiency analysis}

Power loss occurring in DC resistance of inductor is

$$
P_{L}=\sum_{i=1}^{\varnothing} I_{L i(\text { odd }) r m s}^{2} \times D C R_{i(o d d)}
$$

Switching and conduction loss in MOSFET is

$$
\begin{aligned}
& P_{Q 1 s w}=P_{Q 2 s w}=\frac{f V_{\text {in }}}{2(1-d)^{2}}\left\{\left[n I_{O}\left(T_{r}+T_{f}\right)\right]+\cos V_{\text {in }}\right\} ; \\
& P_{Q 1 \text { cond }}+P_{Q 2 \text { cond }}=I_{Q 1 r m s} R_{O N 1}+I_{Q 2 r m s} R_{O N 2}
\end{aligned}
$$

Power loss of in diode and capacitor is

$$
P_{D}=\sum_{i=1}^{N} I_{\text {Davg }} X V_{F}+\sum_{i=1}^{N} I_{D r m s} X V_{F} ; P_{C}=I_{c r m s}^{2} \times E S R
$$

The total power loss is 


$$
P_{\text {Loss }}=P_{L \text { tot }}+\sum_{i=1}^{\emptyset} P_{Q i, s w}+\sum_{i=1}^{\emptyset} P_{Q i, \text { cond }}+\sum_{N=1}^{2 n} P_{D N}+\sum_{N=1}^{2 n} P_{c N}
$$

Efficiency of the converter is

$$
\% \eta=\frac{P_{O}}{P_{O}+P_{\text {Loss }}} \times 100
$$

Efficiency graph is plotted by considering the datasheet of MOSFET, diode, inductor and capacitor. The proposed converter produced maximum efficiency of $97.6 \%$. Figure 3 shows efficiency graph for various loads. It could be observed that for load power of $200 \mathrm{~W}$, efficiency of converter is maximum and for all other powers its value is much lesser.

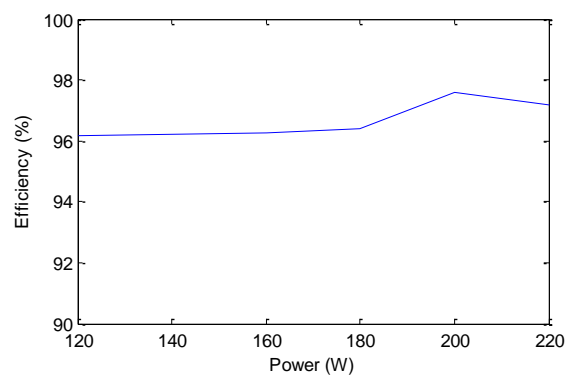

Figure 3. Efficiency of the converter with variable load

\section{SIMULATION OF CIRCUIT}

Circuit is simulated in MATLAB/Simulink software. This high ratio gain converter is designed for power rating of $300 \mathrm{~W}$ with input voltage of $24 \mathrm{~V}$ and output voltage of $400 \mathrm{~V}$ having voltage gain ratio of 16 times. It comprises of two quadratic converters connected in parallel, combination gets connected in series with Dickson Voltage Multiplier. Inductors $\mathrm{L}_{1}, \mathrm{~L}_{2}, \mathrm{~L}_{3}$ and $\mathrm{L}_{4}$ with values of $140 \mu \mathrm{H}, 280 \mu \mathrm{H}, 140 \mu \mathrm{H}$ and $280 \mu \mathrm{H}$ are used in quadratic converter. Design parameters for the simulation system is detailed in Table 1. Inductor current of magnitude 6 A flows through inductor $\mathrm{L}_{1}$ and $\mathrm{L}_{2}, 2.8 \mathrm{~A}$ flows through $\mathrm{L}_{3}$ and $\mathrm{L}_{4}$ as shown in Figure 4 (a). Two switches are selected as high frequency MOSFET switches; they are triggered at the rate of $20 \mathrm{kHz}$. When duty ratio is fifty one percent, for input voltage of $24 \mathrm{~V}$, the output voltage obtained is $400 \mathrm{~V}$ as shown in Figure 4 (b). Output current of 0.49A flows in load resistance of $800 \Omega$. Magnitude of voltage is obtained as $400 \mathrm{~V}$ providing gain ratio of converter as 16 . For this nature this converter can be made suitable for photovoltaic applications.

Table 1. Design parameters for simulation system

\begin{tabular}{cc}
\hline Component & Value \\
\hline Supply voltage, $\mathrm{V}_{\mathrm{s}}$ & $24 \mathrm{~V}$ \\
Output voltage, $\mathrm{V}_{0}$ & $400 \mathrm{~V}$ \\
Input current, $\mathrm{I}_{\mathrm{s}}$ & $12 \mathrm{~A}$ \\
Output current, $\mathrm{I}_{0}$ & $0.49 \mathrm{~A}$ \\
Switching frequency, $\mathrm{f}_{\mathrm{s}}$ & $20 \mathrm{kHz}$ \\
Inductor, $\mathrm{L}_{1}, \mathrm{~L}_{2}$ & $140 \mu \mathrm{H}$ \\
Inductor, $\mathrm{L}_{3}, \mathrm{~L}_{4}$ & $280 \mu \mathrm{H}$ \\
Capacitors & $100 \mu \mathrm{F}$ \\
Resistive load $\mathrm{R}_{\mathrm{L}}$ & $800 \Omega$ \\
\hline
\end{tabular}

Figure 5 (a) shows voltage across first stage capacitor of Dickson voltage multiplier cell, that is around $100 \mathrm{~V}$ and Figure 5 (b) shows voltage across second stage capacitor, which is around 200V from this it could be observed that voltage stress across capacitors is much lesser than output voltage. This necessitates choosing a capacitor of much lower voltage rating compared to output voltage. Figure 6 (a) illustrates current flowing in first stage capacitors. Figure 6 (b) shows the voltage stress of switches. Magnitude of switch voltage is obtained as $100 \mathrm{~V}$ that is four times lower than output voltage. When this situation is compared with any other boost or quadratic boost design, presence of voltage multiplier cell makes the designer to 
select a switch that has very low voltage rating compared to output voltage; thereby switch voltage stress is much lower in proposed converter of this paper. Figure 9 depicts current waveform of inductor. It could be proved interleaving of converter has made presence of low current ripple in input photovoltaic side, that favors for accurate maximum power point design. Figure 7 (a) and Figure 7 (b) depicts voltage measured across diodes of voltage multiplier cell.

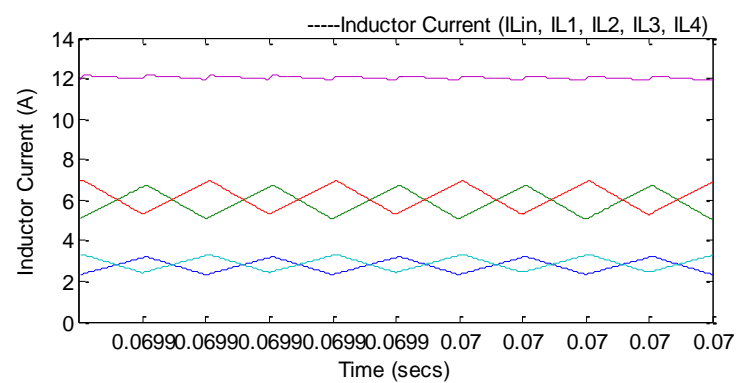

(a)

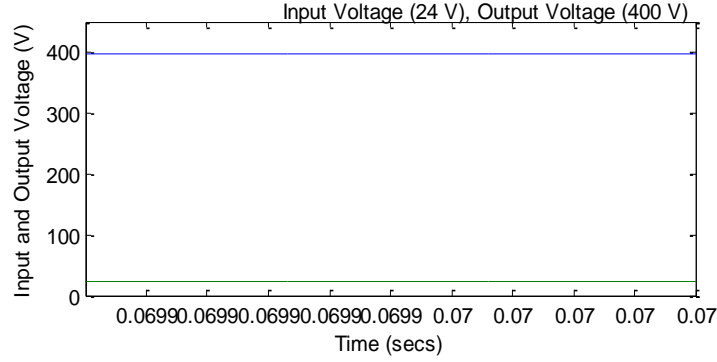

(b)

Figure 4. Simulation waveforms (a) inductor currents and input current and (b) input and output voltage

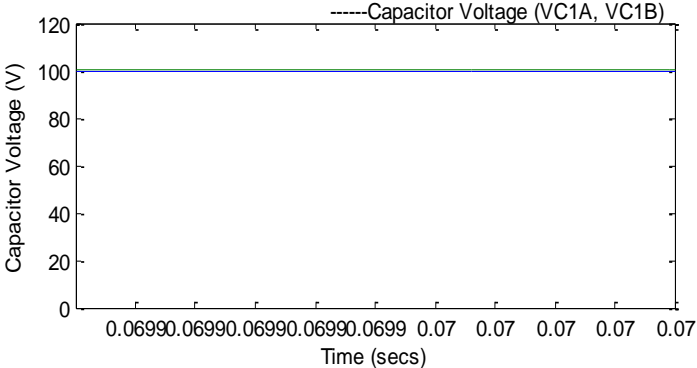

(a)

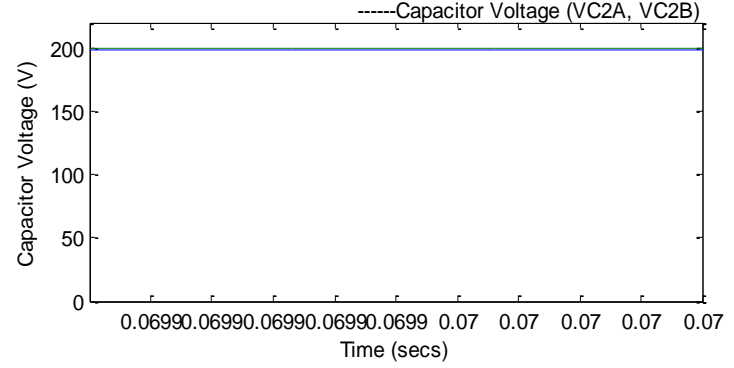

(b)

Figure 5. Simulation waveforms (a) voltage across first stage capacitor and (b) voltage across second stage capacitor of Dickson multiplier cell

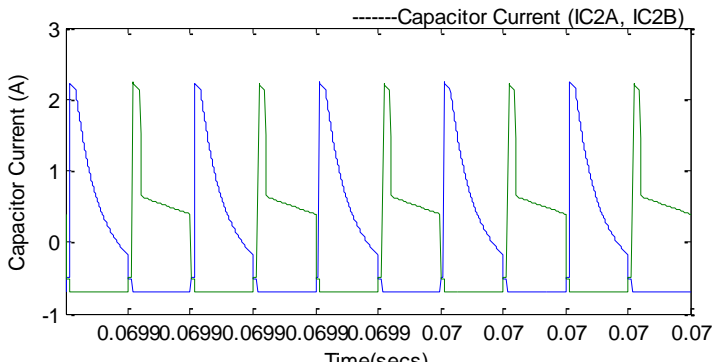

(a)

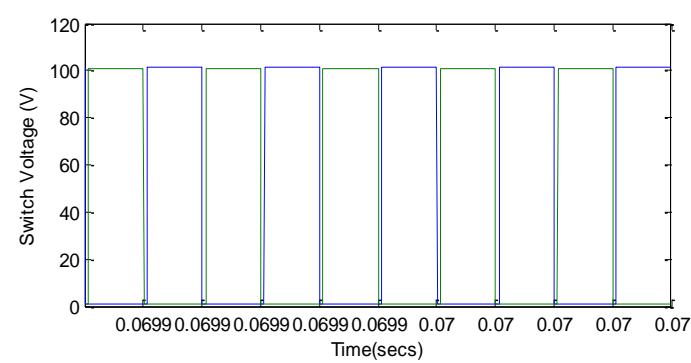

(b)

Figure 6. Simulation waveforms (a) capacitor currents of second stage and (b) Voltage stress across switches SW1 and SW2 


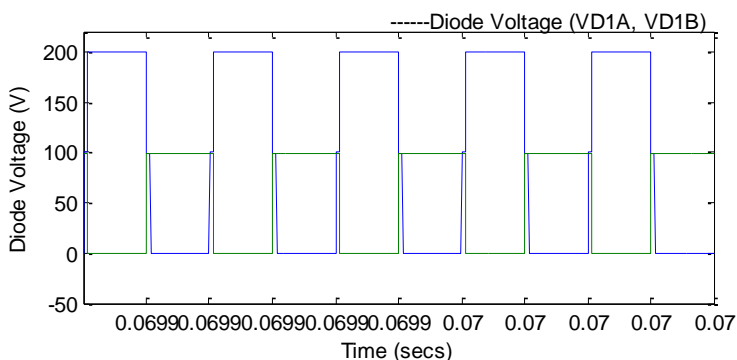

(a)

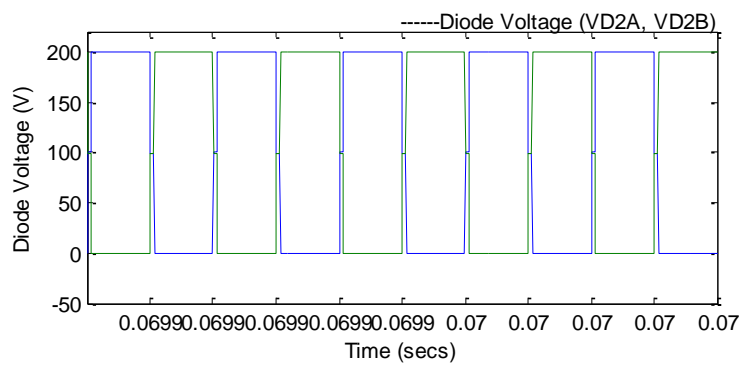

(b)

Figure 7. Simulation waveforms (a) voltage across first stage diode and (b) voltage across second stage diode of Dickson multiplier cell

\section{HARDWARE IMPLEMENTATION}

The proposed circuit is implemented in hardware to validate the design. A prototype of 300W interleaved quadratic boost converter and series connection of Dickson Voltage Multiplier is made. For an input voltage of $24 \mathrm{~V}$ it produces load voltage of $400 \mathrm{~V}$. This property makes converter suitable for photovoltaic applications. PIC16F877A microcontroller was used to produce gate pulse to interleaved quadratic boost converter. Figure 8 (a) shows first stage and second stage capacitor voltage of Dickson Voltage Multiplier Cell. Voltage across first stage capacitor is measured to be $100 \mathrm{~V}$ and second stage capacitor is measured to be $199.5 \mathrm{~V}$.

Figure 8 (b) shows voltage across first stage diodes of Dickson Voltage Multiplier Cell, it is said to be equal to $100 \mathrm{~V}$. Figure 9 (a) shows voltage across second stage diodes of Dickson Voltage Multiplier Cell, it is said to be equal to $200 \mathrm{~V}$. Figure 9 (b) measures input current and output current of the proposed converter, input current is measured to be $11.35 \mathrm{~A}$ and output current is measured to be $0.64 \mathrm{~A}$. As it is said interleaved circuit has reduced input current ripple that reduced value of inductor used in quadratic boost converter circuit. Hence a high-voltage gain which could handle high power is designed. Low value of ripple current of 0.29A from photovoltaic panel, ensures constant current drawn from photovoltaic panel and also enables the use of MPPT technique when required. The use of high value of capacitor produces almost no ripple in output voltage.

Moreover, this converter can be exclusively used for stepping up voltage obtained from photovoltaic panels to input voltage of inverter that converts DC power to AC power and runs single phase induction motors that are used for water pumping, especially in isolated OFF grid photovoltaic powered residential homes. The design is proposed to be an innovative design; because integrated energy storage can be included that eliminates the disadvantage of intermittent power generation of solar panel. Connection of energy storage across capacitor whose voltage is always twice that of input voltage also increases capacity of battery that is used. Depending on power obtained from photo-voltaic panel, three modes of operation occur as given in the Table 2.

As given in Table 2, three different situations are due to the stochastic fluctuation of the photovoltaic power with variation in insolation, here depending upon the power difference happening between the source and load power, the behaviour of the discharge and charge mode of the integrated energy storage, the operation of the circuit is classified into three different cases, where in the first case photo-voltaic power is lesser than the load demand, battery is in discharging state, in the second case photo-voltaic power is greater that load demand, battery is in charging state and in last state photo-voltaic power becomes equal to the load demand battery is in floating state.

Simulation made in MATLAB/Simulink is shown in Figure 10 and the inductor currents during three different power levels between the photovoltaic panel power, battery power and load power is illustrated in Figure 11. Focussing made on magnitude of input current, and inductor currents, justifies the above said concept. In the simulation waveform, from time zero seconds to 0.3 second, photovoltaic power is maintained greater than load power. From 0.3 second to 0.5 second photovoltaic power is reduced such that its magnitude becomes lesser than load power. Now, when transition is made at 0.3 second, the input current transits from higher value to lower value, hence inductor currents $i_{L 1}$ and $i_{L 3}$ also transits from highet value to lower value as they are located before battery. But inductor currents $i_{\mathrm{L} 2}$ and $i_{\mathrm{L} 4}$ is maintained constant instead of reducing, this proves that, excess current to these inductors is supplied from battery. Therefore, batteries connected in parallel to capacitors $\mathrm{C}_{1}$ and $\mathrm{C}_{2}$, maintain constant current in inductors $\mathrm{i}_{\mathrm{L} 2}$ and $\mathrm{i}_{\mathrm{L} 4}$ and thereby maintain constant current in load, irrespective of Photovoltaic power variation. 


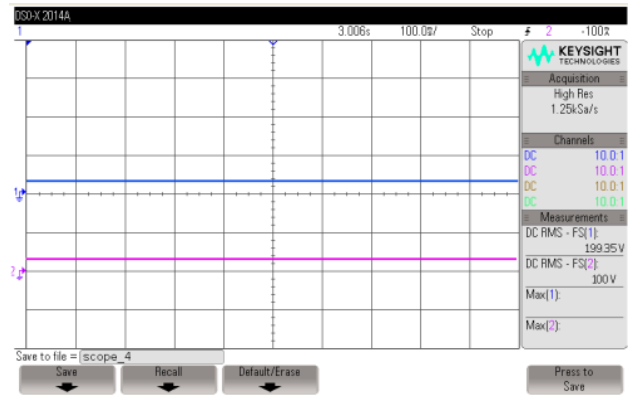

(a)

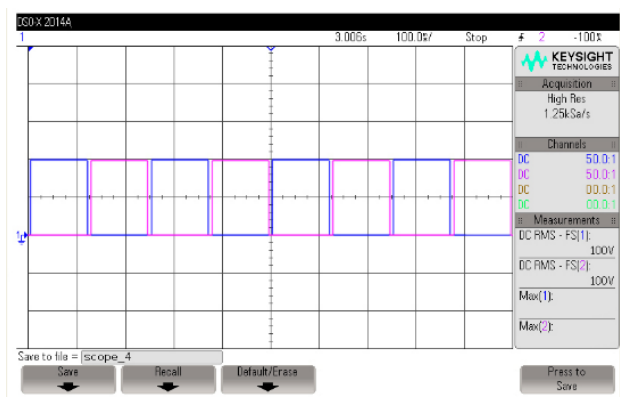

(b)

Figure 8. (a) first stage and second stage capacitor voltages and (b) voltage across the first stage diodes

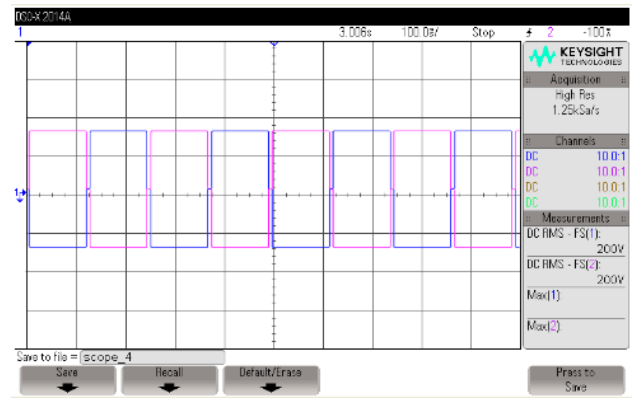

(a)

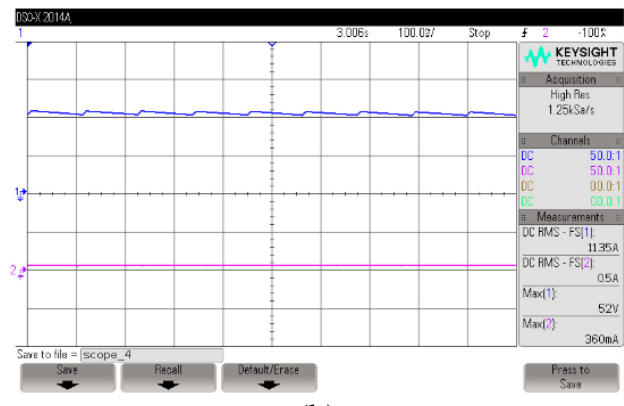

(b)

Figure 9. (a) voltage across second stage diodes and (b) input current and output current of proposed converter

Table 2. Relationship between $\mathrm{P}_{\mathrm{in}}, \mathrm{P}_{\mathrm{o}}$ and $\mathrm{P}_{\mathrm{ba}}$

\begin{tabular}{ll}
\hline Input and Output power relationship & Battery Power \\
\hline $\mathrm{P}_{\text {in }}<\mathrm{P}_{0}$ & $\mathrm{P}_{\text {bat }}>0$, Discharging state \\
$\mathrm{P}_{\text {in }}>\mathrm{P}_{0}$ & $\mathrm{P}_{\text {bat }}<0$, Charging state \\
$\mathrm{P}_{\text {in }}=\mathrm{P}_{0}$ & $\mathrm{P}_{\text {bat }}=0$, Floating state \\
\hline
\end{tabular}

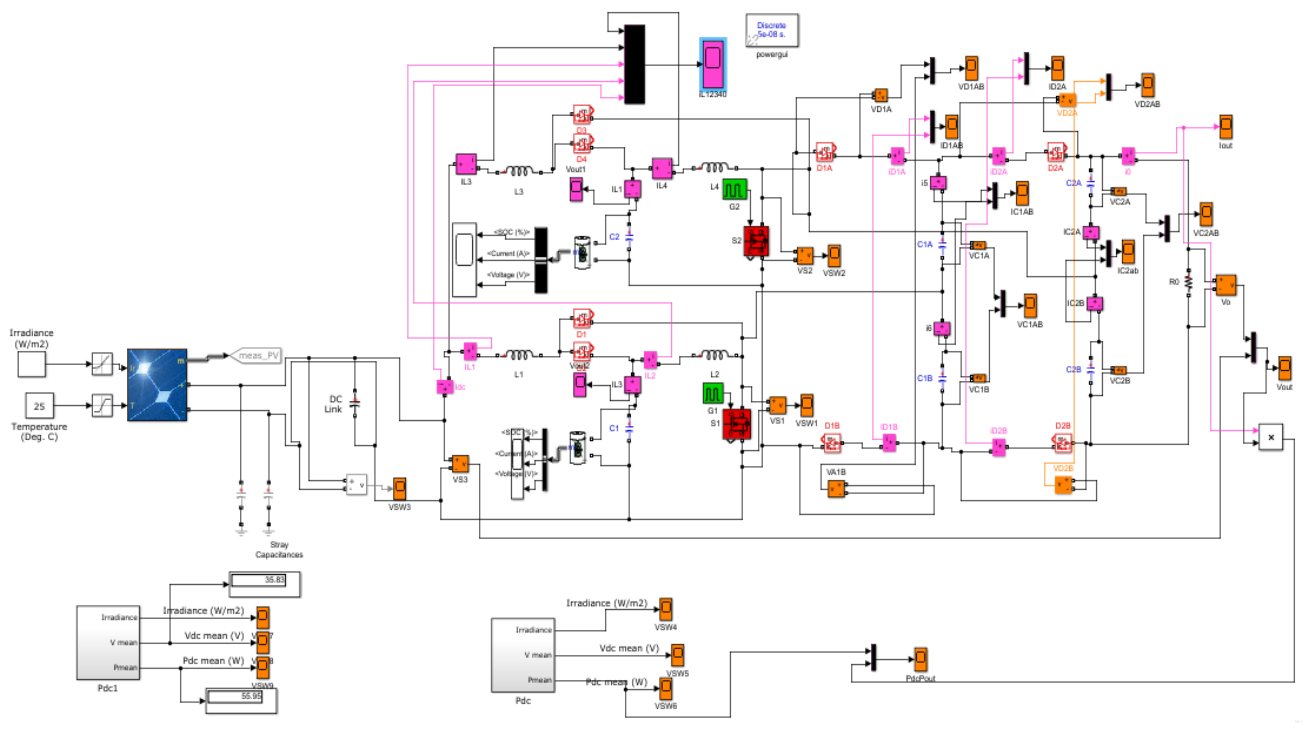

Figure. 10 Simulation of the proposed converter circuit 


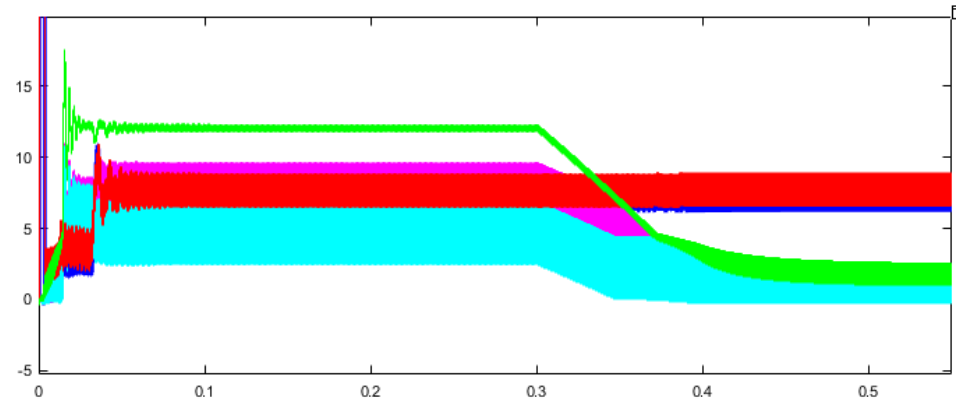

Figure 11. Simulation waveforms: first inductor current, $\mathrm{i}_{\mathrm{L} 1}$ (light blue), $\mathrm{i}_{\mathrm{L} 3}$ (magenta), second inductor current, $\mathrm{i}_{\mathrm{L} 2}$ (red), $\mathrm{i}_{\mathrm{L} 4}$ (dark blue) input current (green colour)

\section{CONCLUSION}

Paper proposed interleaved quadratic boost converter with Dickson voltage multiplier cell. Converter holds the advantage of lesser current ripple in input photovoltaic panel and lesser voltage ripple in output load. Moreover, interleaving had made converter to operate with high photovoltaic power, making them a suitable choice for high power low input side voltage applications. Cascading voltage multiplier cell with interleaved converter produces high gain ratio voltage, which makes converter to be incorporated in power electronic circuits used in interfacing with high voltage applications like grid connected photovoltaic, electric vehicle charging station and battery swapping stations. A $300 \mathrm{~W}$ circuit with input voltage of $24 \mathrm{~V}$ and output voltage of $400 \mathrm{~V}$ is designed, analyzed and simulated in this paper. Prototype is also made to verify simulation results. At the end application of this converter to integrated energy storage is discussed.

\section{REFERENCES}

[1] B. Kroposki, C. Pink, R. DeBlasio, H. Thomas, M. Simões and P. K. Sen, "Benefits of Power Electronic Interfaces for Distributed Energy Systems," in IEEE Transactions on Energy Conversion, vol. 25, no. 3, pp. 901-908, Sept. 2010, DOI: 10.1109/TEC.2010.2053975.

[2] Maral Mahlooji, Ludovic Gaudard, Bora Ristic and Kaveh Madani, "The importance of considering resource availability restrictions in energy planning: What is the footprint of electricity generation in the Middle East and North Africa (MENA)," Science of the Total Environment, pp. 717, 2020, DOI: 10.1016/j.scitotenv.2019.135035.

[3] Gülşah Yilan, M.A. Neşet Kadirgan and Gökçen A. Çiftçioğlu, "Analysis of electricity generation options for sustainable energy decision making: The case of Turkey," Renewable Energy, vol. 146, pp. 519-529, 2020, DOI: 10.1016/j.renene.2019.06.164.

[4] T. L. Nguyen, J. M. Guerrero and G. Griepentrog, "A Self-Sustained and Flexible Control Strategy for Islanded DC Nanogrids Without Communication Links," in IEEE Journal of Emerging and Selected Topics in Power Electronics, vol. 8, no. 1, pp. 877-892, March 2020, DOI: 10.1109/JESTPE.2019.2894564.

[5] Y. Luo, X. Zhang, D. Yang and Q. Sun, "Emission Trading Based Optimal Scheduling Strategy of Energy Hub with Energy Storage and Integrated Electric Vehicles," in Journal of Modern Power Systems and Clean Energy, vol. 8, no. 2, pp. 267-275, March 2020, DOI: 10.35833/MPCE.2019.000144.

[6] Mingfei Ban, Jilai Yu, Mohammad Shahidehpour and Danyang Guo, "Optimal sizing of PV and battery-based energy storage in an off-grid nanogrid supplying batteries to a battery swapping station," J. Mod. Power Syst. Clean Energy, vol. 7. No. 2, pp. 309-320, year 2020, DOI: 10.1007/s40565-018-0428-y.

[7] S. Priyadharsini, T.S. Sivakumaran and C. Kannan, "Performance analysis of photovoltaic-based SL-quasi Z source inverter" International Journal of Energy Technology and Policy. vol. 1, no. 3, 254-264, 2015, DOI: 10.1504/IJETP.2015.073799

[8] M. Veerachary, "Design and analysis of a new quadratic boost converter," 2017 National Power Electronics Conference (NPEC), 2017, pp. 307-313, DOI: 10.1109/NPEC.2017.8310476.

[9] Y. Wang, Y. Qiu, Q. Bian, Y. Guan and D. Xu, "A Single Switch Quadratic Boost High Step Up DC-DC Converter," in IEEE Transactions on Industrial Electronics, vol. 66, no. 6, pp. 4387-4397, June 2019, DOI: 10.1109/TIE.2018.2860550.

[10] S. Sadaf, M. S. Bhaskar, M. Meraj, A. Iqbal and N. Al-Emadi, "A Novel Modified Switched Inductor Boost Converter with Reduced Switch Voltage Stress," in IEEE Transactions on Industrial Electronics, vol. 68, no. 2, pp. 1275-1289, Feb. 2021, DOI: 10.1109/TIE.2020.2970648.

[11] A. Siadatan, S. Tahzibi, R. Babaloo and J. Gotlieb, "Simple Switched-Inductor High-Gain Boost converter," 2020 International Symposium on Power Electronics, Electrical Drives, Automation and Motion (SPEEDAM), 2020, pp. 733-737, DOI: 10.1109/SPEEDAM48782.2020.9161926. 
[12] A. Maroufkhani, D. KazemiKia and K. Abbaszadeh, "A new single-switch soft-switched high-step up DC-DC converter based on magnetic coupling," 2020 11th Power Electronics, Drive Systems, and Technologies Conference (PEDSTC), 2020, pp. 1-6, DOI: 10.1109/PEDSTC49159.2020.9088359.

[13] J. Park, W. Choi and B. Kwon, "A Step-Up DC-DC Converter with a Resonant Voltage Doubler," in IEEE Transactions on Industrial Electronics, vol. 54, no. 6, pp. 3267-3275, Dec. 2007, DOI: 10.1109/TIE.2007.906174.

[14] S. Ben-Yaakov, "On the Influence of Switch Resistances on Switched-Capacitor Converter Losses," in IEEE Transactions on Industrial Electronics, vol. 59, no. 1, pp. 638-640, Jan. 2012, DOI: 10.1109/TIE.2011.2146219.

[15] S. Li, Y. Zheng, B. Wu and K. M. Smedley, "A Family of Resonant Two-Switch Boosting Switched-Capacitor Converter with ZVS Operation and a Wide Line Regulation Range," in IEEE Transactions on Power Electronics, vol. 33, no. 1, pp. 448-459, Jan. 2018, DOI: 10.1109/TPEL.2017.2669841.

[16] A. Ioinovici, H. S. H. Chung, M. S. Makowski and C. K. Tse, "Comments on "Unified Analysis of SwitchedCapacitor Resonant Converters"," in IEEE Transactions on Industrial Electronics, vol. 54, no. 1, pp. 684-685, Feb. 2007, DOI: 10.1109/TIE.2006.885454.

[17] Y. Mahnashi and F. Z. Peng, "Generalization of the Fundamental Limit Theory in a Switched-Capacitor Converter," in IEEE Transactions on Power Electronics, vol. 32, no. 9, pp. 6673-6676, Sept. 2017, DOI: 10.1109/TPEL.2017.2679106.

[18] C. Cheung, S. Tan, C. K. Tse and A. Ioinovici, "On Energy Efficiency of Switched-Capacitor Converters," in IEEE Transactions on Power Electronics, vol. 28, no. 2, pp. 862-876, Feb. 2013, DOI: 10.1109/TPEL.2012.2204903.

[19] Hassan M.H. Farh, Ali M. Eltamaly, and Mamdooh S. Al-Saud, "Interleaved boost converter for global maximum power extraction from the photovoltaic system under partial shading," IET Renewable Power Gener, vol. 13, pp. 1232-1238, year 2019, DOI: 10.1049/iet-rpg.2018.5256.

[20] L. Xu, Y. Huangfu, Q. Li, R. Ma, D. Zhao and Q. Zhang, "Robust Control of a Interleaved Boost Converter Which Feeds a Constant Power Load for Electric Vehicles," 2019 IEEE Transportation Electrification Conference and Expo (ITEC), 2019, pp. 1-6, DOI: 10.1109/ITEC.2019.8790527.

[21] J. Prakash and M. Veerachary, "A Coupled Inductor assisted Soft-Switching Interleaved Boost Converter," 2020 IEEE International Conference on Power Electronics, Smart Grid and Renewable Energy (PESGRE2020), 2020, pp. 1-6, DOI: 10.1109/PESGRE45664.2020.9070336.

[22] T. Zeng, Z. Wu and L. He, "An Interleaved Soft Switching High Step-Up Converter with Low Input Current Ripple and High Efficiency," in IEEE Access, vol. 7, pp. 93580-93593, 2019, DOI: 10.1109/ACCESS.2019.2928227.

[23] A. Alzahrani, M. Ferdowsi and P. Shamsi, "A Family of Scalable Non-Isolated Interleaved DC-DC Boost Converters with Voltage Multiplier Cells," in IEEE Access, vol. 7, pp. 11707-11721, 2019, DOI: 10.1109/ACCESS.2019.2891625.

[24] A. Alzahrani, M. Ferdowsi and P. Shamsi, "High-Voltage-Gain DC-DC Step-Up Converter with Bifold Dickson Voltage Multiplier Cells," in IEEE Transactions on Power Electronics, vol. 34, no. 10, pp. 9732-9742, Oct. 2019, DOI: 10.1109/TPEL.2018.2890437.

[25] D. Amudhavalli, N. K. Mohanty and A. K. Sahoo, "High power high gain non-isolated interleaved quadratic boost converter with voltage multiplier cell," 2018 Technologies for Smart-City Energy Security and Power (ICSESP), 2018, pp. 1-6, DOI: 10.1109/ICSESP.2018.8376736.

[26] A. Alzahrani, M. Ferdowsi and P. Shamsi, "High-Voltage-Gain DC-DC Step-Up Converter with Bifold Dickson Voltage Multiplier Cells," in IEEE Transactions on Power Electronics, vol. 34, no. 10, pp. 9732-9742, Oct. 2019, DOI: 10.1109/TPEL.2018.2890437.

[27] B. P. Baddipadiga and M. Ferdowsi, "A high-voltage-gain dc-dc converter based on modified Dickson charge pump voltage multiplier," in IEEE Transactions on Power Electronics, vol. 32, no. 10, pp. 7707-7715, Oct. 2017, DOI: 10.1109/TPEL.2016.2594016.

[28] M. L. Alghaythi, R. M. O'Connell, N. E. Islam, M. M. S. Khan and J. M. Guerrero, "A High Step-Up Interleaved DC-DC Converter with Voltage Multiplier and Coupled Inductors for Renewable Energy Systems," in IEEE Access, vol. 8, pp. 123165-123174, 2020, DOI: 10.1109/ACCESS.2020.3007137.

[29] M. L. Alghaythi, R. M. O'Connell, N. E. Islam, M. M. S. Khan and J. M. Guerrero, "A High Step-Up Interleaved DC-DC Converter with Voltage Multiplier and Coupled Inductors for Renewable Energy Systems," in IEEE Access, vol. 8, pp. 123165-123174, 2020, DOI: 10.1109/ACCESS.2020.3007137.

[30] Shin-Ju Chen, Sung-Pei Yang, Chao-Ming Huang and Yu-Hua Chen, "Interleaved High Step-Up DC-DC Converter with Voltage-Lift and Voltage-Stack Techniques for Photovoltaic Systems,” Energies, vol. 13, pp. 2537, year 2020 .

[31] S. Athikkal, K. Sehgal, U. Mohan and A. Singh, "A Voltage Multiplier based Non-Isolated High Gain DC-DC Converter for DC Bus Application," 2020 International Conference on Futuristic Technologies in Control Systems \& Renewable Energy (ICFCR), 2020, pp. 1-6, DOI: 10.1109/ICFCR50903.2020.9249974. 